At-Tijaroh : Jurnal Ilmu Manajemen dan Bisnis Islam

Volume 5 Nomor 1 Ed. Jan - Juni 2019 : Hal 139 - 153

p-ISSN : $2356-492 x$

e-ISSN : $2549-9270$

\title{
DETERMINAN KEPUTUSAN PERUSAHAAN MENGGUNAKAN ALUMNI EKONOMI SYARIAH
}

\author{
Delima Sari Lubis ${ }^{1}$ \\ Institut Agama Islam Negeri Padangsidimpuan \\ ${ }^{1}$ Jl. H.T. Rizal Nurdin Km. 4,5 Sihitang, Padangsidimpuan, Sumatera Utara \\ ${ }^{1}$ delimasarilubis@gmail.com
}

\begin{abstract}
The study was conducted to determine the effect of education, experience, expertise, and character on company decisions using Islamic Economics graduates. The data processed in this study is primary data that obtained through distributing questionnaires to companies using graduates of Islamic Economics. The number of research samples was 40 companies. The data obtained were analyzed using multiple linear regression equations through the equation KepPer $=a+b_{1} P e n+b 2 P e n g+b_{3} K+$ $b 4 K P+e$. Education, experience, expertise, and character contributed 56\% to the company's decision to use Islamic economic graduates and the remaining $44 \%$ was contributed by other factors outside the research. Variables that significantly influence the company's decision to use Islamic economic graduates consist of; education. While the variables that do not influence the company's decision to use Islamic economic Islamic economic are characters. Simultaneously all independent variables have a significant effect on the bound.
\end{abstract}

Keywords : Corporate Decisions, Education, Character.

\begin{abstract}
Abstrak
Penelitian bertujuan untuk mengetahui pengaruh pendidikan, pengalaman, keahlian, dan karakter terhadap keputusan perusahaan menggunakan alumni Ekonomi Syariah. Data yang diolah dalam penelitian ini berupa data primer yang diperoleh melalui penyebaran kuesioner kepada perusahaan pengguna alumni jurusan Ekonomi Syariah. Jumlah sampel penelitian sebanyak 40 responden atau perusahaan. Data yang diperoleh dianalisis dengan menggunakan persamaan regresi linier berganda melalui persamaan KepPer $=a+b_{1} P e n+$ $\mathrm{b}_{2}$ Peng $+\mathrm{b}_{3} \mathrm{~K}+\mathrm{b}_{4} \mathrm{KP}+$ e. Pendidikan, pengalaman, keahlian, dan karakter memiliki kontribusi sebesar 56\% terhadap keputusan perusahaan menggunakan alumni Ekonomi Syariah dan 44\% sisanya disumbangkan oleh faktor-faktor lain di luar penelitian.Variabel yang signifikan mempengaruhi keputusan perusahaan dalam menggunakan alumni ekonomi syariah terdiri dari pendidikan. Sedangkan variabel yang tidak mempengaruhi keputusan perusahaan dalam menggunakan alumni ekonomi syariah adalah karakter. Secarasimultan semua variabel bebas berpengaruh secara signifikan terhadap terikat.
\end{abstract}

Kata Kunci: Keputusan Perusahaan, Pendidikan, Karakter.

\section{PENDAHULUAN}

Sebuah perusahaan dituntut untuk mampu mengelola perusahaan dengan berbagai sumber daya yang tersedia. Terlepas dari jenis, ukuran, produk, maupun jasa yang dihasilkan, perusahaan tentu membutuhkan sejumlah karyawan untuk mengisi berbagai 


\section{Determinan Keputusan Perusahaan Menggunakan Alumni Ekonomi Syariah}

posisi yang tersedia. Pengisian kekosongan tersebut dapat disebabkan oleh berbagai faktor, antara lain; pertumbuhan dan perkembangan perusahaan, perubahan struktur dan fungsi, ataupun perputaran karyawan. Pengisian kekosongan tersebut bertujuan untuk mempertahankan kemampuan perusahaan dalam bersaing dengan perusahaan lain atau agar mampu mengikuti berbagai perubahan yang terjadi. Salah satu aset perusahaan yang paling berharga dalam menghadapi berbagai tantangan dan kesulitan yang ada adalah Sumber Daya Manusia (SDM). Peran dan tantangan SDM semakin banyak dan terus berkembang, beraneka ragam, rumit, fleksibel dan tentu saja penting seiring dengan perkembangan perusahaan. Pentingnya peranan SDM tercermin dari kebijakan yang dilakukan perusahaan untuk mengatur SDM-nya, sehingga dapat memberi peran optimal dalam mendukung tujuan perusahaan.

Tujuan perusahaan akan tercapai jika proses untuk memperoleh, menyeleksi, dan menempatkan tenaga kerja dilakukan secara optimal. Hal ini disebabkan karena faktor tenaga kerja merupakan faktor penentu bila dibanding dengan faktor lain. Oleh karena itu, tenaga kerja yang cakap adalah salah satu faktor penting bagi perusahaan, khususnya di negara-negara yang sedang berkembang. Setiap perusahaan apapun bentuknya akan membutuhkan sejumlah tenaga kerja dalam melaksanakan setiap fungsi kegiatan yang ada di dalam perusahaan tersebut, karena menyangkut masalah maju mundurnya perusahaan. Maka, seleksi tenaga kerja diperlukan untuk melanjutkan kelangsungan hidup, pertumbuhan atau keuntungan yang diharapkan perusahaan. Seleksi tenaga kerja dimaksudkan untuk memilih tenaga kerja cakap yang diperlukan untuk memenuhi kebutuhan perusahaan, baik di masa sekarang maupun masa akan datang.

Oleh karenanya, semua kebutuhan tenaga kerja harus diketahui secara dini oleh pemimpin perusahaan, sehingga seleksi tenaga kerja mampu menyediakan kebutuhan tenaga kerja terhadap lowongan-lowongan yang disebabkan oleh perpindahan, adanya lowongan baru dan lowongan yang kosong. Pada umumnya, proses seleksi dilaksanakan dengan mencari calon karyawan yang memiliki kemampuan intelegensi yang tinggi, dan tekad yang kuat dalam melaksanakan pekerjaan. Upaya-upaya peningkatan keterampilan dan kemampuan karyawan dilakukan oleh perusahaan melalui pengembangan dan pelatihan kerja, guna menciptakan karyawan yang memiliki etos kerja serta prestasi kerja yang tinggi. Pada akhirnya, strategi seleksi turut mempertimbangkan kecocokan antara individu dengan perusahaan, disamping faktor pengetahuan, keterampilan, dan kemampuan yang dimiliki oleh calon karyawan akan memberikan hasil yang positif bagiperusahaan. Semakin efektif proses seleksi, semakin besar kemungkinan untuk mendapatkan pegawai yang tepat bagi perusahaan. Selain itu, seleksi yang efektif akan berpengaruh langsung pada prestasi kerja karyawan dan kinerja finansial perusahaan. Dengan demikian maka pengembangan dan perencanaan sistem seleksi merupakan hal penting untuk dilaksanakan setiap perusahaan 
supaya proses yang berlangsung cukup lama dan biaya yang dikeluarkan tidak sia-sia.

Sebagai sebuah institusi pendidikan tingkat tinggi, Institut Agama Islam Negeri (IAIN) Padangsidimpuan terus berusaha menciptakan lulusan-lulusan yang berkualitas, siap pakai, dan memiliki daya saing di dunia kerja. Maka Fakultas Ekonomi dan Bisnis Islam (FEBI) sebagai salah satu fakultas yang ada di lingkungan IAIN Padangsidimpuan terus berusaha memberikan yang terbaik bagi para mahasiswanya. Hal ini dilakukan karena FEBI menyadari bahwa usaha untuk menciptakan lulusan berkualitas sebagaimana penjelasan di atas harus dilakukan sejak dini serta berkesinambungan. Baik dalam hal pendidikan (yang tergambar dari kurikulum), ekstrakurikuler yang diberikan (untuk menunjang keahlian), penguatan karakter kepribadian (sebagai Sarjana Ekonomi (SE) syariah/Islam), maupun kegiatan-kegiatan penunjang kualitas mahasiswa lainnya. Hal ini tentu saja sejalan dengan visi jurusan Ekonomi Syariah.

Jurusan Ekonomi Syariah pertama kali menerima mahasiswa pada tahun 2012, ketika itu masih sebagai prodi di bawah naungan jurusan Syariah. Akan tetapi sejak STAIN alih status menjadi IAIN, maka prodi Ekonomi Syariah juga alih status menjadi Jurusan di bawah FEBI. Jumlah mahasiswa yang berminat terhadap jurusan Ekonomi Syariah terus meningkat setiap tahun. Sebut saja pada tahun 2017, jumlah peminat Ekonomi Syariah sebanyak 1.110 orang, dan yang dinyatakan lulus hanya sebanyak 508 orang. Hingga saat ini jurusan Ekonomi Syariah telah menamatkan alumni sebanyak 311 orang. Berdasarkan survei awal yang dilakukan melalui tracer studi, bahwa sebahagian alumni sudah bekerja diberbagai perusahaan dan pada berbagai posisi/jabatan. Hanya saja masih sangat sedikit alumni yang bekerja sesuai bidang ilmu. Adapun jenis perusahaan tempat alumni bekerja juga cukup bervariasi, diantaranya; perusahaan jasa (perbankan, lembaga keuangan non bank, hotel, sekolah, konsultan), perusahaan dagang (distributor, sales), maupun bidang pemerintahan. Berikut tabel yang mendeskripsikan sebaran distribusi pekerjaan alumni Ekonomi Syariah.

Tabel 1

Distribusi Pekerjaan Alumni

\begin{tabular}{|c|c|c|c|c|c|c|}
\hline \multirow{2}{*}{$\begin{array}{l}\text { Periode } \\
\text { Wisuda }\end{array}$} & \multirow{2}{*}{ Jumlah } & \multicolumn{4}{|c|}{ Terdata bekerja } & \multirow{2}{*}{$\begin{array}{l}\text { Belum } \\
\text { terdata }\end{array}$} \\
\hline & & Per. Jasa & Per. Dagang & Industri & Lain-Lain & \\
\hline Juni 2016 & 27 & 6 & 4 & 3 & 10 & 4 \\
\hline Nop 2016 & 84 & 15 & 20 & 25 & 15 & 9 \\
\hline Juni 2017 & 104 & 5 & 15 & 10 & 35 & 39 \\
\hline Nop 2017 & 96 & - & - & - & - & 96 \\
\hline & Total & 26 & 39 & 38 & 60 & 148 \\
\hline
\end{tabular}

Berdasarkan data sebaran pekerjaan alumni di atas, maka pihak jurusan dan fakultas, 


\section{Determinan Keputusan Perusahaan Menggunakan Alumni Ekonomi Syariah}

harus terus berupaya agar jumlah mahasiswa yang banyak ini memiliki kemampuan dan keahlian yang sesuai dengan tuntutan dunia usaha. Sehingga mampu bersaing dengan alumni perguruan tinggi lain untuk diterima bekerja pada sebuah perusahaan. Oleh karena itu, untuk meningkatkan kualitas mahasiswa dan khususnya alumni dimasa mendatang, maka banyak hal yang perlu dan harus dilakukan oleh pihak jurusan dan fakultas. Salah satu diantaranya perlu diketahui berbagai alasan atau kriteria yang ditetapkan pihak perusahaan dalam merekrut karyawannya. Dengan demikian, pihak terkait dalam institusi ini mampu menyiapkan hal dimaksud, misalnya melalui pengembangan dan penyesuaian kurikulum.

Berdasarkan berbagai latar belakang di atas, maka peneliti tertarik untuk mengetahui lebih dalam berbagai faktor yang mempengaruhi keputusan perusahaan menggunakan alumni Ekonomi Syariah.

\section{TINJAUAN TEORITIK}

\subsection{Keputusan Perusahaan}

Untuk menghadapi persaingan bisnis yang semakin kompetitif, dinamis, dan cenderung sulit diprediksi, maka setiap perusahaan membutuhkan ketersediaan Sumber Daya Manusia (SDM) yang cakap, terampil, berkeahlian, serta responsif terhadap perubahan. Berbagai perubahan yang terus terjadi membawa konsekuensi logis bagi perusahaan untuk selalu mengantisipasi dan mampu menyesuaikan dengan perubahan tersebut. Salah satu langkah yang dapat dilakukan adalah perencanaan SDM. Menurut Cascio dalam Safarudin Alwi, menjelaskan bahwa perencanaan SDM akan menjadi lebih penting bagi perusahaan karena globalisasi, teknologi baru, proses restrukturisasi organisasi, dan perbedaan etnis dalam angkatan kerja (Alwi, 2001).

Eksistensi perusahaanyang tumbuh dan berkembang di tengah-tengah lingkungan bisnis yang semakin kompetitif memerlukan SDM yang berkualitas. Dalam era teknologi dan informasi, tuntutan kualitas SDM harus disesuaikan dengan kebutuhan perusahaan. Hal ini penting karena kemajuan dan kecanggihan teknologi yang tidak diimbangi dengan tersedianya SDM yang mumpuni dalam mengoperasikan peralatan modern yang dimilikip erusahaan, akan sangat mempengaruhi tingkat keberhasilan dalam mencapai tujuan-tujuan yang telah ditetapkan. Salah satu penyebab minimnya kualitas SDM dalam suatu perusahaan dapat diakibatkan adanya kesalahan dalam perencanaan/proyeksi SDM, sehingga hal ini dapat menghambat kecepatan pencapaian tujuan. Perusahaan yang tidak didukung pegawai/karyawan yang sesuai baik dari aspek kuantitas, kualitas, strategi, dan operasional yang baik, maka perusahaan tersebut akan sulit mempertahankan dan mengembangkan eksistensinya dimasa yang akan datang.

\subsection{Perencanaan Sumber Daya Manusia}


Menurut Arthur W Sherman dan Goerge W Bohlander dalam Hadari Nawawi, mendefinisikan perencanaan SDM adalah proses mengantisipasi dan membuat ketentuan untuk mengatur arus gerakan tenaga kerja ke dalam, di dalam, dan ke luar organisasi (Nawawi, 1997). Sementara menurut Stoiner, dikatakan bahwa perencanaan SDM merupakan perencanaan yang bertujuan untuk mempertahankan dan meningkatkan kemampuan organisasi dalam mencapai tujuan, melalui strategi pengembangan kontribusi pekerjanya di masa depan (Nawawi, 1997). Safarudin Alwi berpendapat bahwa perencanaan SDM adalah perencanaan yang disusun pada tingkat operasional yang diajukan untuk memenuhi permintaan SDM dengan kualifikasi yang dibutuhkan. Perencanaan SDM pada dasarnya dibutuhkan ketika perencanaan bisnis sebagai implementasi visi dan misi perusahaan telah ditetapkan. Berawal dari strategi bisnis kemudian strategi perencanaan SDM apa yang akan dipilih. Strategi SDM yang dipilih dan ditetapkan sangat menentukan kebutuhan SDM seperti apa yang akan diinginkan, baik secara kuantitas maupun kualitas (Alwi, 2001). Sementara perencanaan SDM menurut Graham dan Benet dalam Safarudin Alwi dikatakan bahwa perencanaan SDM sebagai upaya memproyeksikan berapa banyak karyawan dan macam apa yang dibutuhkan organisasi dimasa yang akan datang (Alwi, 2001).

Dari berbagai definisi tersebut, dapat disimpulkan bahwa perencanaan SDM merupakan proses menentukan kebutuhan SDM, secara kuantitatif dan kualitatif untuk mencapai tujuan perusahaan melalui fungsi-fungsi MSDM dalam jangka pendek maupun jangka panjang secara efektif dan efisien. Dalam memenuhi kebutuhan tenaga kerja saat ini atau jangka pendek, maka proses perencanaan SDM bertujuan untuk mengisi kekurangan tenaga kerja baik secara kuantitas maupun kualitas. Sedangkan untuk memenuhi kebutuhan tenaga kerja di masa datang atau jangka panjang, maka perencanaan SDM lebih menekankan pada forecasting akan ketersediaan tenaga kerja yang didasarkan pada kebutuhan sesuai dengan rencana bisnis di masa datang. Dengan kata lain, tujuan perencanaan SDM adalah untuk mempergunakan SDM seefektif mungkin agar memiliki sejumlah pekerja yang memenuhi persyaratan/kualifikasi dalam mengisi posisi yang kosong kapanpun dan apapun posisi tersebut. Dengan tersedianya informasi tentang kebutuhan dan kualifikasi yang diinginkan, maka dalam pelaksanaan rekrutmen, seleksi, penempatan, pemeliharaan, pengembangan, dan pemberian kesejahteraan karyawan akan lebih mudah dan terkendali.

Perguruan tinggi, sebagai lembaga pendidikan tertinggi di negeri ini memiliki peran penting dalam mencetak manusia yang handal dan berkualitas, sehingga dapat menjawab tantangan zaman. Perlu disadar bahwa SDM merupakan gerakan human investment, yaitu upaya pendidikan jangka panjang untuk melahirkan SDM. Pengembangan SDM bukan merupakan persoalan yang mudah karena membutuhkan pemikiran, langkah aksi yang 


\section{Determinan Keputusan Perusahaan Menggunakan Alumni Ekonomi Syariah}

sistematik, dan keseriusan pihak-pihak yang terkait di dalamnya. Karena berusaha memberikan konstruksi yang utuh tentang manusia dengan mengembangkan seluruh potensi dasar manusia. Oleh karena itu, pengembangan kualitas manusia perlu diprogramkan sedemikian rupa agar dapat sesuai dengan tuntutan pengembangan perusahaan atau bahkan pembangunan sebuah negara.

\subsection{Unsur-Unsur Sumber Daya Manusia}

Unsur-unsur SDM meliputi kemampuan-kemampuan, sikap, nilai-nilai, kebutuhankebutuhan, dan karakteristik demografisnya. Unsur-unsur tersebut sangat dipengaruhi oleh lingkungan sekitar. Seperti norma-norma dan nilai-nilai masyarakat, tingkat pendidikan dan peluang-peluang yang tersedia. Unsur-unsur tersebut pada gilirannya akan mempengaruhi peranan dan perilaku manusia dalam sebuah perusahaan. Perbedaan-perbedaan seperti itu sangat penting untuk diketahui oleh manajer, sehingga dapat diakomodasikannya. Pengakuan atas perbedaan potensi-potensi itu juga menuntut adanya penyesuaian manajer terhadap karakteristik-karakteristik tersebut. Di tengah era persaingan bebas saat ini, eksistensi SDM akan dipengaruhi oleh kemampuannya terhadap penguasaan ilmu pengetahuan dan teknologi, pemantapan iman dan takwa (Shiddiqie, 1996), serta kepribadian yang dimiliki. Penguasaan terhadap pengetahuan dan teknologi dapat diperoleh di tempat dimana manusia itu belajar. Sedangkan kepribadian dan ketakwaan juga bisa dipengaruhi di lingkungan yang bagaimana manusia tersebut berada.

\subsection{Faktor-Faktor Yang Memengaruhi Perusahaan Menggunakan Alumni}

Pertama, pendidikan; dalam hal ini latar belakang pendidikan diduga memiliki kaitan yang erat dengan keputusan perusahaan memilih karyawan. Karyawan yang memiliki latar belakang pendidikan tertentu biasanya akan terlihat prestasinya pada seleksi tentang bidang yang dikuasainya. Latar belakang pendidikan dapat dilihat dari dua sisi, yaitu kesesuaian antara bidang ilmu yang ditempuh dengan bidang tugas (spesifikasi keilmuan) dan jenjang pendidikan. Kedua bagian ini sekaligus menjadi indikator dari penelitian ini.

Jenjang Pendidikan Menurut Undang-Undang Sistem Pendidikan Nasional No. 20 tahun 2003 adalah tahapan pendidikan yang ditetapkan berdasarkan tingkat perkembangan peserta didik, tujuan yang akan dicapai dan kemampuan yang dikembangkan. Jenjang pendidikan formal terdiri dari: pendidikan dasar, pendidikan atas, dan pendidikan tinggi. Spesifikasi/jurusan keilmuan dianalisis agar dapat ditempatkan pada posisi jabatan yang sesuai dengan kualifikasi pendidikannya. Dengan demikian karyawan dapat memberikan kinerja yang baik bagi perusahaan.

Kedua, pengalaman; pengalaman kerja merupakan kegiatan melakukan segala sesuatu yang pernah dialami oleh seseorang. Pengalaman kerja akan dapat memberikan keuntungan bagi seseorang dalam melaksanakan kerja selanjutnya karena setidaknya orang tersebut sudah pernah melakukan pekerjaan itu sehingga ia akan tahu tentang pekerjaan 
yang akan dihadapi. Oleh karena itu, pengalaman kerja sangat membantu seseorang untuk mempersiapkan diri menghadapi pekerjaan yang mungkin sama dengan pekerjaan yang baru. Seorang karyawan yang memiliki pengalaman kerja lebih banyak tentu akan lebih mengerti apa yang harus dilakukan ketika menghadapi masalah. Selain itu karyawan yang telah memiliki pengalaman kerja lebih banyak pasti akan lebih cepat dalam bekerja dan tidak harus beradaptasi dengan tugas yang dijalankan.

Pengalaman kerja atau masa kerja adalah tingkat pengetahuan serta keterampilan seseorang yang dapat diukur dari masa kerja seseorang. Sehingga semakin lama seseorang bekerja semakin bertambah pengalamannya terhadap pekerjaannya. Dengan banyaknya pengalaman kerja yang dimiliki seseorang pekerja maka orang tersebut akan lebih menguasai pekerjaannya, sehingga dapat menyelesaikan pekerjaannya dengan baik ini berarti orang tersebut mempunyai efektivitas kerja yang baik. Faktor-faktor yang mempengaruhi pengalaman kerja sekaligus sebagai indikator pengalaman kerja yaitu: lama waktu/masa kerja dan tingkat pengetahuan atau keterampilan yang dimiliki. Pengetahuan merujuk pada konsep, prinsip, prosedur, kebijakan atau informasi lain yang dibutuhkan oleh pegawai. Pengetahuan juga mencakup kemampuan untuk memahami dan menerapkan informasi pada tanggung jawab pekerjaan.

Ketiga, keahlian; menurut Robbins dan Judge keahlian adalah kapasitas individu untuk melakukan beragam tugas dalam suatu pekerjaan. Keahlian adalah sebuah penilaian seorang individu yang pada dasarnya terdiri atas dua faktor, yaitu faktor intelektual dan fisik. Sedangkan Lowser dan Poter mendefinisikan bahwa keahlian sebagai karakteristik individual seperti intelegensia, manual skill, traits yang merupakan kekuatan potensial seseorang untuk berbuat dan sifatnya stabil. Keahlian pada individu ditentukan oleh tiga aspek yaitu: kondisi sensoris dan kognitif, pengetahuan tentang cara respon yang benar, dan keahlian melaksanakan respon tersebut. Menurut Chaplin "keahlian bisa merupakan kesanggupan bawaan sejak lahir, atau merupakan hasil latihan atau praktek”. Keahlian mencakup tiga indikator, yaitu: Pertama, keahlian teknik (technical skill), meliputi; kemampuan untuk menerapkan pengetahuan atau keahlian khusus. Kedua, keahlian kemanusiaan (human skill) ,kemampuan untuk bekerja sama, memahami, dan memotivasi orang lain, baik secara individual maupun dalam kelompok. Ketiga, Keahlian konsep (conceptual skill), yaitu kemampuan mental untuk menganalisis dan mendiagnosis situasisituasi yang rumit.

Keempat, karakter pribadi; kepribadian menurut Gordon W. Allport adalah suatu organisasi yang dinamis dari sistem psiko-fisik indvidu yang menentukan tingkah laku dan pemikiran individu secara khas. Dinamis artinya bahwa perilaku seseorang bisa saja berubah-ubah melalui proses pembelajaran atau melalui pengalaman, reward, punishment, 


\section{Determinan Keputusan Perusahaan Menggunakan Alumni Ekonomi Syariah}

pendidikan, dan sebagainya. Kepribadian merupakan sifat dan karakteristik tertentu, yang relatif permanen, konsistensi maupun individualitas pada perilaku seseorang. Kepribadian merupakan serangkaian ciri yang relatif tetap dan sebagain besar dibentuk oleh faktor keturunan, sosial, kebudayaan dan lingkungan.

\subsection{Kerangka Pikir dan Hipotesis}

Berdasarkan kajian teori dan penelitian terdahulu kerangka pikir dalam penelitian ini digambarkan sebagai berikut :

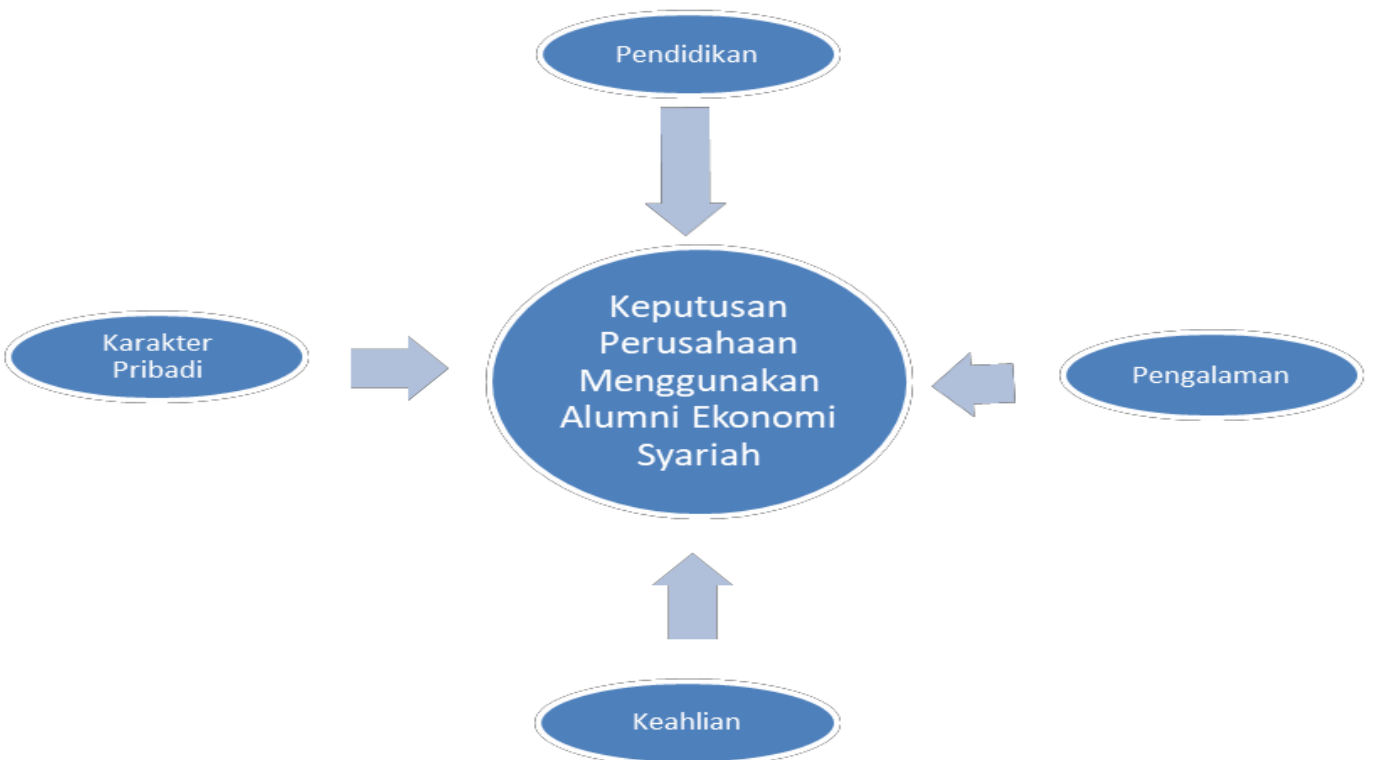

Hipotesis dalam penelitian ini adalah :

Ho : Tidak terdapat pengaruh antara pendidikan, pengalaman, keahlian, dan karakter pribadi terhadap keputusan perusahaan menggunakan alumni Ekonomi Syariah secara simultan.

$\mathrm{Ha}$ : Terdapat pengaruh antara pendidikan, pengalaman, keahlian, dan Karakter pribadi terhadap keputusan perusahaan menggunakan alumni Ekonomi Syariah secara simultan.

\section{METODE PENELITIAN}

Penelitian ini dilakukan dengan metode penelitian kuantitatif dengan menggunakan jenis data primer, yang berasal dari perusahaan atau instansi yang mempekerjakan alumni ekonomi syariah. Pengumpulan data primer yang dilakukan dalam penelitian ini menggunakan kuesioner dalam bentuk skala likert. Sampel penelitian sebanyak 40 perusahaan, dimana kuesionernya diisi oleh atasan alumni. Teknik analisa data dilakukan dengan bantuan SPSS (Statistical Product and Service Solution) Versi 23. Tahapan analisa data adalah; uji validitas dan uji reliabilitas, uji normalitas, uji linieritas, uji asumsi klasik (multikolineritas, autokorelasi dan heteroskedastisitas), uji hipotesis (parsial dan simultan, 
koefisien determinasi), Analisis persamaan regresi linier berganda, dengan model persamaan regresi

$$
\text { KepPer }=\mathrm{a}+\mathrm{b}_{1} \text { Pen }+\mathrm{b}_{2} \text { Peng }+\mathrm{b}_{3} \mathrm{~K}+\mathrm{b}_{4} \mathrm{KP}+\mathrm{e} .
$$

Keterangan:

$\begin{array}{ll}\text { KepPer } & \text { : Keputusan perusahaan } \\ \text { a } & \text { : konstansta } \\ \text { b1,b2,b3,b4 } & \text { : koefisien } \\ \text { regresi Pen } & \text { : Pendidikan } \\ \text { Peng } & \text { : Pengalaman } \\ \text { K } & \text { : Keahlian } \\ \text { KP } & \text { : Karakter Pribadi } \\ \text { e } & : \text { Error Term }\end{array}$

\section{HASIL DAN PEMBAHASAN}

\subsection{Uji Validitas dan Reliabilitas}

Untuk menentukan butir soal valid atau tidak valid, dilakukan dengan membandingkan nilai r_tabel dengan r-hitung. Dimana, jika r-tabel < r-hitung, maka butir pernyataan dikatakan valid, demikian sebaliknya. Berdasarkan hasil uji validitas disimpulkan bahwa setiap butir pernyataan pada semua variabel yang diajukan dinyatakan valid, karena nilai r-tabel $(0,210)<$. nilai $r$-hitung semua pernyataan. Dan jika dilihat berdasarkan nilai signifikansi, maka semua butir pernyataan memiliki nilai signifikansi $<10 \%$. semua variabel yang digunakan dalam penelitian ini memenuhi unsur reliabilitas. Dimana 2 variabel dinyatakan cukup reliabel, 1 dinyatakan reliabel dan 2 variabel masuk pada kategori sangat reliabel.

\subsection{Uji Normalitas}

Uji normalitas penelitian ini dilakukan dengan metode pengujian Kolmogrov- Semirnov (KS). Kesimpulan dari hasil uji normalitas dilihat dari nilai Absolut. Dimana nilai absolut dari; keputusan perusahaan (0,256), pendidikan (0,342), pengalaman (0,263), keahlian $(0,155)$, dan karakter $(0,262)$. Nilai absolut semua variabel berada di atas 0,10 . Artinya bahwa semua variabel penelitian dinyatakan memenuhi asumsi uji normalitas.

\subsection{Uji Asumsi Klasik}

Uji multikolineritas, penelitian ini terbebas dari masalah asumsi klasik multikolineritas. Hal ini diketahui dari nilai tolerance yang berada di atas 0,10 untuk semua jenis variabel bebas. Di samping itu, juga dapat dilihat dari nilai VIF semua variabel bebas yang lebih kecil dari 10,00 (Lihat tabel 2). Sedangkan uji heterokedastisitas dengan menggunakan uji korelasi Spearman's Rho menyimpulkan bahwa nilai korelasi keempat 


\section{Determinan Keputusan Perusahaan Menggunakan Alumni Ekonomi Syariah}

variabel independen dengan unstandardized residual memiliki nilai signifikansi lebih dari 0,10. Karena signifikansi lebih dari o,10 maka dapat disimpulkan bahwa tidak terjadi masalah heteroskedastisitas pada model regresi. Adapun untuk uji autokorelasi, dilakukan dengan menggunakan uji Durbin- Watson (DW). Kriteria uji DW adalah $-2<$ DW $<+2$, maka disimpulkan tidak terjadi masalah autokorelasi, karena nilai DW $>-2$ dan $<+2(-2<0,980<2)$ (Lihat tabel 4).

\subsection{Uji Hipotesis}

Pengujian hipotesis secara parsial dilakukan dengan membandingkan nilai t- hitung dengan nilai t-tabel. Nilai t-tabel dapat dilihat pada tabel statistik pada signifikansi $10 \%$ atau o,10 dengan derajat kebebasan $\mathrm{df}=\mathrm{n}-\mathrm{k}-1$. Dimana $\mathrm{n}$ adalah jumlah sampel dan $\mathrm{k}$ adalah jumlah variabel independen, sehingga nilai t-tabel dalam penelitian ini sebesar 1,655. Berdasarkan kriteria yang ada maka disimpulkan secara parsial, yaitu pendidikan memiliki pengaruh yang signifikan secara parsial terhadap keputusan perusahaan dalam menggunakan alumni Ekonomi Syariah $(4,181>1,655$ atau 0,00o < 0,10. Sehingga Ho ditolak dan Ha diterima. Kesimpulannya, bahwa terdapat pengaruh yang signifikan antara pendidikan terhadap keputusan perusahaan dalam menggunakan alumni Ekonomi Syariah, dan pengalaman memiliki pengaruh yang signifikan secara parsial terhadap keputusan perusahaan dalam menggunakan alumni Ekonomi Syariah (-2,645>1,655 atau 0,012 < 0,10. Sehingga Ho ditolak dan Ha diterima. Kesimpulannya, bahwa terdapat pengaruh yang signifikan antara pengalaman terhadap keputusan perusahaan dalam menggunakan alumni Ekonomi Syariah, keahlian memiliki pengaruh yang signifikan secara parsial terhadap keputusan perusahaan dalam menggunakan alumni Ekonomi Syariah (1,379 > 1,655 atau o,091 < 0,10. Sehingga Ho ditolak dan Ha diterima. Kesimpulannya, bahwa terdapat pengaruh yang signifikan antara keahlian terhadap keputusan perusahaan dalam menggunakan alumni Ekonomi Syariah, karakter tidak memiliki pengaruh yang signifikan secara parsial terhadap keputusan perusahaan dalam menggunakan alumni Ekonomi Syariah $(0,425<1,655$ atau 0,673 > 0,10. Sehingga Ho diterima dan Ha ditolak. Kesimpulannya, bahwa tidak terdapat pengaruh yang signifikan antara karakter terhadap keputusan perusahaan dalam menggunakan alumni Ekonomi Syariah. Berikut tabel yang menunjukkah hasil uji hipotesis.

\section{Tabel 2}


Hasil Uji Hipotesis Penelitian Secara Parsial

\begin{tabular}{|c|c|c|c|c|c|c|c|}
\hline \multirow[t]{2}{*}{ Model } & \multicolumn{2}{|c|}{$\begin{array}{c}\text { Unstandardize } \\
\mathrm{d} \\
\text { Coefficients }\end{array}$} & \multirow{2}{*}{$\begin{array}{l}\text { Standardize } \\
\text { d } \\
\text { Coefficients } \\
\text { Beta }\end{array}$} & \multirow[t]{2}{*}{$\mathrm{T}$} & \multirow[t]{2}{*}{ Sig. } & \multicolumn{2}{|c|}{$\begin{array}{l}\text { Collinearity } \\
\text { Statistics }\end{array}$} \\
\hline & B & Std. Error & & & & Tolerance & VIF \\
\hline (Constant) & 6,651 & 3,578 & & 1,859 & ,071 & & \\
\hline Pendidikan &, 714 & 171 & ,605 & 4,181 & ,000 & ,601 & 1,664 \\
\hline Pengalaman &,- 302 & ,114 &,- 567 & $-2,645$ & ,012 & ,274 & 3,651 \\
\hline Keahlian & ,277 & 159 & ,365 & 1,739 & ,091 & ,286 & 3,495 \\
\hline Karakter & ,072 & (169 & , 064 & ,425 & 673 & ,559 & 1,790 \\
\hline
\end{tabular}

Hasil uji simultan, dapat dilihat dari tabel berikut ini.

Tabel 3

Hasil Uji Hipotesis Penelitian Secara Simultan

\begin{tabular}{|ll|r|r|r|c|c|}
\hline Model & Sum of Squares & Df & Mean Square & F & Sig. \\
\hline $\mathbf{1}$ & Regression & 55,289 & 4 & 13,822 & 11,125 & ,o00 \\
& Residual & 43,486 & 35 & 1,242 & & b \\
Total & 98,775 & 39 & & & \\
\hline
\end{tabular}

Berdasarkan tabel 3 di atas, dapat dilihat nilai F-hitung (11,125) > F- tabel 2,72, sehingga Ho ditolak dan Ha diterima. Artinya secara simultan semua variabel bebas penelitian ini mempengaruhi variabel terikat. Selain itu berdasarkan nilai signifikansi $(0,000)<0,10$. Sehingga pengaruh secara simultan tersebut dinyatakan signifikan. Berikut tabel hasil uji simultan.

Koefisien korelasi penelitian tergambar dari nilai R sebesar 0,748 (Lihat tabel 4.9). Nilai ini dapat diinterpretasikan bahwa hubungan variabel bebas dan variabel terikat pada penelitian ini dikategori kuat (berada diantara 0,60- 0,799). Melalui tabel tersebut juga diperoleh nilai $\mathrm{R}$ Square atau koefisien determinasi yang menunjukkan seberapa bagus model regresi yang dibentuk oleh interaksi variabel bebas dan variabel terikat. Nilai $\mathrm{R}^{2}$ yang diperoleh sebesar 0,560. Angka ini dapat ditafsirkan bahwa variabel bebas (pendidikan, pengalaman, keahlian, dan karakter) memiliki kontribusi sebesar 56\% terhadap variabel terikat (keputusan perusahaan menggunakan alumni Ekonomi Syariah) dan 44\% sisanya disumbangkan oleh faktor-faktor lain di luar penelitian. Berikut tabel yang menunjukkan hasil uji koefisien determinasi.

\section{Tabel 4}


150 Determinan Keputusan Perusahaan Menggunakan Alumni Ekonomi Syariah

Hasil Uji Koefisien Determinasi

\begin{tabular}{|l|c|r|r|r|c|}
\hline Model & $\mathrm{R}$ & R Square & $\begin{array}{c}\text { Adjusted R } \\
\text { Square }\end{array}$ & $\begin{array}{c}\text { Std. Error of the } \\
\text { Estimate }\end{array}$ & $\begin{array}{l}\text { Durbin- } \\
\text { Watson }\end{array}$ \\
\hline $\mathbf{1}$ & $\begin{array}{c}, 748 \\
\mathrm{a}\end{array}$ &, 560 &, 509 & 1,115 &, 980 \\
\hline
\end{tabular}

Model persamaan regresi yang diperoleh dengan koefisien konstanta dan koefisien variabel yang ada di kolom Unstandardized Coefficients B. (Lihat tabel 2). Berdasarkan tabel tersebut diperoleh model persamaan regresi: KepPres = 6,651 + 0,714 Pen + (-0,302) Peng + 0,277 K + 0,072 KP. Konstanta sebesar 6,651. Artinya jika semua variabel bebas dianggap konstan, maka keputusan perusahaan menggunakan alumni ekonomi syariah sebesar 6,651 satuan. Koefisien pendidikan sebesar 0,714. Artinya jika tingkat pendidikan seseorang seorang alumni meningkat 1 satuan, maka keputusan perusahaan menggunakan alumni ekonomi syariah akan meningkat sebesar 0,71 satuan. Koefisien bernilai positif, artinya antara tingkat pendidikan dengan keputusan perusahaan menggunakan alumni ekonomi syariah memiliki hubungan yang searah. Koefisien pengalaman sebesar -0,302. Artinya jika pengalaman yang diberikan dimiliki seorang alumni meningkat 1 satuan, maka keputusan perusahaan menggunakan alumni ekonomi syariah akan berkurang sebesar 0,30 satuan. Koefisien bernilai negatif, artinya antara pengalaman dengan keputusan perusahaan menggunakan alumni ekonomi syariah memiliki hubungan berbanding terbalik. Koefisien keahlian sebesar 0,277. Artinya jika keahlian yang dimiliki alumni meningkat 1 satuan, maka keputusan perusahaan menggunakan alumni ekonomi syariah akan meningkat sebesar 0,277 satuan. Koefisien bernilai positif, artinya antara keahlian dengan keputusan perusahaan menggunakan alumni ekonomi syariah memiliki hubungan yang searah. Koefisien karakter pribadi sebesar 0,072. Artinya jika karakter pribadi yang dimiliki alumni meningkat 1 satuan, maka keputusan perusahaan menggunakan alumni ekonomi syariah akan meningkat sebesar 0,072 satuan. Koefisien bernilai positif, artinya antara karakter pribadi dengan keputusan perusahaan menggunakan alumni ekonomi syariah memiliki hubungan yang searah.

\subsection{Pembahasan Hasil Penelitian}

Hasil penelitian ini didukung oleh teori dan berbagai penelitian terdahulu, antara lain pertama, penelitian Sunarta, yang menyimpulkan, bahwa perencanaan SDM merupakan upaya memproyeksikan berapa banyak karyawan dan kualifikasi karyawan yang dibutuhkan organisasi dimasa yang akan datang. Setiap perusahaan harus menentukan masa depannya dengan berbagai rencana yang relevan dengan tuntutan zaman. Dalam konteks ini, perencanaan SDM akan menjadi lebih penting bagi perusahaan karena globalisasi, teknologi baru, dan proses restrukturisasi perusahaan. Satu hal yang tidak boleh diabaikan adalah pentingnya integrasi atau keterpaduan antara perencanaan bisnis dengan 
perencanaan SDM. Perencanaan bisnis yang diikuti dengan perencanaan SDM yang baik akan menghasilkan tingkat efektivitas dan efisiensi pencapaian tujuan perusahaan. Sebaliknya, perencanaan bisnis yang tidak diikuti perencanaan SDM yang baik hanya akan melahirkan biaya tinggi dan penggunaan sumber daya yang tidak efektif. Agar pelaksanaan perencanaan SDM berhasil, maka ada empat aspek yang harus diperhatikan, yaitu: proyeksi jumlah karyawan yang dibutuhkan (forecasting of employees), identifikasi SDM yang tersedia (human resource audit), analisis keseimbangan penawaran dan permintaan (demand and suplay analysis), serta menjalankan program aksi (action program). Oleh karena itu, pendidikan tinggi juga harus melihat dan menyesuaikan kurikulum terhadap yang diterapkan sehingga alumninya kelak dapat diterima oleh berbagai perusahaan.

Kedua, penelitian M. Nazar menyimpulkan bahwa tanggung jawab utama manajemen SDM meliputi; perencanaan sumber daya manusia; perekrutan dan penyeleksian; pengembangan tenaga kerja; Memberikan kompensasi dan tunjangan; pemberhentian karyawan (perampingan dan outsourcing). Pemanfaatan sumber daya manusia adalah proses kegiatan pemimpin yang bermaksud mempekerjakan pegawai yang memberi prestasi cukup dan tidak mempekerjakan pegawai yang tidak bermanfaat. Upaya untuk meningkatkan SDM dalam pendidikan Islam adalah meningkatkan pembinaan perguruan agama; memantapkan pembinaan peserta didik agar menjadi manusia yang beriman dan bertaqwa, meningkatkan peran pendidikan agama dalam perkembangan ilmu teknologi, serta keterlibatan pendidikan tinggi agama dalam ajang ilmiah untuk memahami dan menghayati dan menterjemahkan ajaran agama sesuai dengan kehidupan masyarakat. Dalam hal ini sebagaimana penelitian, ternyata karakter juga menjadi faktor yang mempengaruhi keputusan perusahaan. Oleh karenyanya kurikulum juga harus berbasis peningkatan kualitas karakter mahasiswa, sehingga mahasiswa kelak menjadi alumni yang memiliki karakter islami.

Ketiga, lowser dan Poter menyatakan bahwa keahlian sebagai karakteristik individual seperti intelegensia, manual skill, traits yang merupakan kekuatan potensial seseorang untuk berbuat dan sifatnya stabil. Keahlian pada individu ditentukan oleh tiga aspek yaitu: kondisi sensoris dan kognitif, pengetahuan tentang cara respon yang benar, dan keahlian melaksanakan respon tersebut. Sejalan dengan teori tersebut bahwa keahlian juga ternyata mempengaruhi keputusan perusahaan. Maka fakultas atau jurusan harusnya menyiapkan mahasiswa atau alumni yang memiliki skill khusus, sebagai bekal untuk bersaing di dunia kerja.

Keempat, sehubungan dengan hasil penelitian, yang menyimpulkan bahwa pengalaman tidak memiliki pengaruh terhadap keputusan perusahaan. Maka Gordon W. Allport menyimpulkan bahwa suatu organisasi yang dinamis dari sistem psiko-fisik 
152 Determinan Keputusan Perusahaan Menggunakan Alumni Ekonomi Syariah

indvidu yang menentukan tingkah laku dan pemikiran individu secara khas. Dinamis artinya bahwa perilaku seseorang bisa saja berubah-ubah melalui proses pembelajaran atau melalui pengalaman, reward, punishment, pendidikan, dan sebagainya. Kepribadian merupakan sifat dan karakteristik tertentu, yang relatif permanen, konsistensi maupun individualitas pada perilaku seseorang. Kepribadian merupakan serangkaian ciri yang relatif tetap dan sebagain besar dibentuk oleh faktor keturunan, sosial, kebudayaan dan lingkungan. Dengan demikian, pengalaman seseorang akan terus berubah sesuai dengan kondisi sosial lingkungannya.

\section{KESIMPULAN}

Jurusan Ekonomi Syariah memiliki mahasiswa yang berasal dari latarbelakang yang berbeda-beda. Baik daerah asal sekolah maupun kemampuan orang tua. Jumlah peminat jurusan ini terus meningkat setiap tahunnya. Oleh karena itu, pihak jurusan, fakultas maupun institusi harus terus berupaya memberikan pendidikan yang terbaik bagi mahasiswanya. Pendidikan tersebut dapat melalui penetapan kurikulum yang berbasis permintaan dunia kerja. Hal ini penting dilakukan agar para alumni mampu ditampung oleh dunia kerja. Sehingga pada akhirnya akan menjadi cara promosi untuk meningkatkan jumlah peminat yang lebih berkualitas dimasa mendatang. Disisi lain, melalui hasil penelitian ini, ternyata pendidikan, keahlian, dan karakter calon pegawai atau karyawan menjadi salah satu faktor yang sangat mempengaruhi keputusan perusahaan untuk mempekerjakan seseorang. Ketiga hal yang berpengaruh tersebut dapat ditempa di pendidikan tinggi melalui kurikulum yang tepat dan menunjang.

\section{DAFTAR PUSTAKA :}

B., Siswanto, Pengantar Manajemen, Jakarta: Bumi Aksara, 2005.

Barthos, Basir, Manajemen Sumber Daya Manusia Suatu Pendekatan Makro, Jakarta: Bumi Aksara, 1990.

Duwi, Priyatno, SPSS 22 Pengolah Data Terpraktis, Yogyakarta : Andi Offset, 2014. Ernie Trisnawati, Sule, dan Kurniawan Saefullah, Pengantar Manajemen, Jakarta:Kencana Prenada Media Group, 2005.

Henry, Simamora, Manajemen Sumber Daya Manusia, Edisi Kedua, Yogyakarta: STIE YKPN, 1997.

Jimmly, Ash-Shidiqie. Sumber Daya Manusia Untuk Indonesia Masa Depan. Bandung: Mizan, 1996.

Juliansyah, Noor, Metodologi Penelitian, Jakarta : Kencana, 2015.

Leon, Schiffin, dan Leslie Lazar Kanuk, Perilaku Konsumen, Jakarta: PT. Indeks, 2008. 
M., Manullang, Dasar-dasar Manajemen, Jakarta: Ghalia Indonesia, 1983.

M. Nasar Almasri, Manajemen Sumber Daya Manusia: Implementasi Dalam Pendidikan Islam, dalam Jurnal Kutubkhanah: Jurnal Penelitian Sosial Keagamaan, Vol. 19 No. 2 Januari-Desember 2016.

Melayu, S.P., Hasibuan Manajemen: Dasar, Pengertian, dan Masalah, Jakarta: Bumi Aksara, 2003.

Morrison, Metode Penelitian Survei, Jakarta : Kencana, 2014.

Mudrajad, Kuncoro. Metode Riset untuk Bisnis dan Ekonomi, Jakarta: Erlangga, 2003.

Nawawi, Hadari, Manajemen Sumber Daya Manusia Untuk Bisnis yang Kompetitif,Yogyakarta: Gadjah Mada University Press, 1997.

Nembah, Hartimbul Ginting, Manajemen Pemasaran, Bandung: CV. Yrama Widya, 2011.

Nugroho J., Setiadi,Perilaku Konsumen, Jakarta: Kencana, 2003.

Panji, Anoraga, Manajemen Bisnis, Jakarta: Rineka Cipta, 2009.

Philip dan Kotler, Manajemen Pemasaran, Jakarta: Erlangga, 2002.

Safarudin, Alwi. Manajemen Sumber Daya Manusia, Yogyakarta: BPFE UGM, 2001. Sondang, P., Siagian, Manajemen Sumber Daya Manusia, Jakarta: Bumi Aksara, 2003. Sunarta, Perencanaan Sumber Daya Manusia (Kunci Keberhasilan Organisasi), FISE

Universitas Negeri Yogyakarta.

Swasta dan Hani Handoko, Manajemen, Jakarta: PT. Raja Grafindo, 2000. Syafaruddin, Pengambilan Keputusan Pendidikan, Jakarta: PT. Grasindo, 2004.

Syofian, Siregar, Statistik Parametrik untuk Penelitian Kuantitatif, Jakarta: Bumi Aksara, 2014.

W Sutjipto, Budi, Paradigma Baru Manajeman Sumber Daya Manusia, Yogyakarta: Amara Book, 2002. 